\title{
PROBLEM AREAS IN THE REPUBLIC OF SRPSKA WITHIN THE SUSTAINABLE DEVELOPMENT CONTEXT
}

\author{
Milenko Živkovićc ${ }^{*}$ Dragan Papićc ${ }^{* 1}$ \\ * University of Banjaluka - Faculty of Natural Sciences and Mathematics, \\ Banjaluka, Bosnia and Herzegovina
}

\begin{abstract}
The paper attempts to identify and define the poorly developed (problem) areas in the Republic of Srpska (a Bosnia and Herzegovina entity), the specificities of their geo-systems, the fundamental development issues and comparative development benefits, with an aim to minimize the spatial (regional) development disparities and reach the territorial cohesion and sustainable development. In order to single out the problem areas, it is necessary to define an adequate development strategy, i.e. to plan and conduct the crucial development processes based upon the identification and valorization of autochthone development potentials. The constant evident spatial-development disparity, the social-economic issues and differences, and the problems of population movement and distribution are all crucial issues of the Republic of Srpska and Bosnia and Herzegovina sustainable development.
\end{abstract}

Keywords: polarization, problem areas, center-periphery, sustainable development.

\section{Introduction}

In shortest, problem areas may be defined as territorial units with recognized development problems. Problem areas are commonly being defined and singled out according to "the spatial-structural and development characteristics", i.e. to which extent they lag in comparison with "the supraregional systems, the whole states, or other political-economic associations" (Тошић, 2012,

\footnotetext{
1 Corresponding author: D. Papić, University of Banjaluka - Faculty of Natural Sciences and Mathematics, Dr. Mladena Stojanovića 2, 78000 Banjaluka, Bosnia and Herzegovina; e-mail: dragan.papic@pmf.unibl.org
} 
103-104). According to Matišić and Pejnović (2015), problem areas are actually territorial units with an evident lack of state progress (commercial, social, etc.), which makes a country's total development even more difficult to achieve. Other authors share the identical opinion on this matter. Hence, it is possible to provisionally define a problem area (region) as a spatial unit which, to a certain extent, deviates from the national average in vital segments of development processes.

The problem areas became a scientific subject matter in 1930s as there was a need to overcome development issues in the mining-industrial areas (regions) in Great Britain, Germany, United States and some other countries. Hence, a law was adopted, to define the Special Areas in Great Britain in 1934 and it was then that the "problem area" term was introduced for the first time.

Ever since the 1960s rapid industrialization and evident spatial development disproportions, the problems of the unbalanced polarized development and problem areas have been in the limelight. It was back then that most countries started to institutionalize regional policy in order to decrease the development disparities. In addition, the emergence and consequences of polarized development are being addressed by the theory of polarized development, which comprises several different concepts. The concept of "center-periphery" relation, the theoretical basis of which was provided by John Friedmann is recognized as one of the most adequate one dealing with the aforementioned issue.

Nevertheless, it is European Union that is also facing the development disparity issue. EU problem areas are being tackled by planning instruments and policies of regional development. In line with the aforementioned, regional planning pays a special attention is paid to spatial units characterized by certain development problems. A harmonized regional development within the EU regional policy rests upon the Territorial Cohesion Policy (Mourato and TewdrwJones, 2012).

Problem areas result from a whole range of development factors. Both scientific and social practices use several different criteria in order to classify and single them out. In addition, most these criteria are based on qualitative and quantitative indicators which point out the nature of current problems (Тошић, 2012; Winkler, 2012). Throughout time, the methodology of identification and singling out problem areas has been improved and adjusted to the economic, social, ecological, and other spatial and development state of affairs. Hagel proposed the following types of areas according to the cause of appearance: commercially undeveloped areas, heavily built-up and preoccupied areas, areas of degraded natural basis, and areas threatened by natural disasters (Тошић, 2012).

Within our target context, most of the Republic of Srpska geographical space is characterized as a problem area. If we take into account Hagel's classification, we may refer to the Republic of Srpska as a commercially undeveloped area. 
Furthermore, it is a result of a whole range of development factors (both natural and social-historical), development policies, modern development regionalgeographical factors (the breakup of former SFR Yugoslavia), war destruction, system transition, global processes, etc.

The Republic of Srpska (RS) is a political-territorial subject (entity) within Bosnia and Herzegovina (B\&H). As a part of $\mathrm{B} \& \mathrm{H}$, it belongs to the Southeast European countries association, or to be more precise, it is a part of the West Balkan geographical space. The entire region is a "European periphery", i.e. a problem area, and $\mathrm{B} \& \mathrm{H}$ is the poorest developed part of the region. The bordering countries around the Republic of Srpska, i.e. Bosnia and Herzegovina (Serbia, Croatia, Montenegro) share similar and even identical development problems, i.e. their problem areas are frequently within Bosnia and Herzegovina (the Republic of Srpska) bordering region and are distinctive problem territorial units (geosystems). Unfortunately, the defined problem in this geographic area is poorly recognized, meaning that it is insufficiently treated and applied in both science and practice when compared to the well-developed parts of the world and finally geographical space of European Union.

Further dichotomy between the problem areas of the Republic of Srpska and its other spatial units may lead towards additional weakening of spatialfunctional integration of the Republic of Srpska and Bosnia and Herzegovina as a whole and it may affect its integration with the regional environment.

\section{Methodological approach}

The criteria used to single out problem areas must comply with the problem itself and should consider how the problem actually affected the formation of such areas along with the regional-geographical approach.

A conditional differentiation of the Republic of Srpska geographical space in several territorial units of different development levels was performed on the basis of empirical understandings and the comparative analysis method by using different indicators within the fields of demography (spatial population distribution), settlement (network and functional capacity of municipal centers, functional connection among municipal centers), and social-economic and other relevant parameters, also taking into account the basic principles of "center-periphery" concept. In other words, based on the territorial distribution of population, internal migrations, number and degree of development of settlement functions (central and labor), mean annual daily car traffic and functional connections among development nods (municipal centers), we applied different social-economical parameters (number of employees per 1,000 inhabitants, GDP per an inhabitant, percentage of highly-educated population within the total number of employees, etc.) in order to 
single out basic indicators of a conditional differentiation of the defined area, which further resulted in territorial units of diverse degrees of spatial-functional organization and development. Therefore, the method of geographical synthesis helped us estimate the degree of spatial (regional) integrity and social-economic and socialgeographical cohesion of the space. The analytical synthesis was performed in order to determine the development processes and problems as well as the complementary development advantages of the problem area geospatial systems. In addition, the tangible guidelines for sustainable development were assumed. The analysis of spatial-structural and functional characteristics was conducted at the level of basic administrative-territorial units (municipalities), which were assumed to be the constructive elements of the defined nodal-functional regional systems (Figure 1) and the basic principle in order to single out problem areas for the planning purposes.

The applied methodology focusing on social-geographical processes is in compliance with modern tendencies of the advanced regional-geography schools. More specifically, the result was the identification and concise definition of geo-space systems within the Republic of Srpska problem areas, which was further to be taken as the starting point for the sustainable development design.

Hence, the primary goal of the paper is to identify and define the poorly developed (problem) areas in the Republic of Srpska, which is a prerequisite for spatial harmonization and reduction of spatial-development disparities, i.e. territorial cohesion and sustainable development.

\section{Results and discussion}

The geospace of Bosnia and Herzegovina, i.e. the Republic of Srpska, is dominated by the Dinaride mountain-lowland geosystem bounded with Pannonian basin in north and the Adriatic Sea in south. The natural-geographical geodiversity and its specificities, along with particularities of cultural and civilization impacts (central European, Oriental, Mediterranean) determine the diversity of natural and cultural heritage as well as the development circumstances.

The Republic of Srpska is characterized by different geographical features, potentials, diverse opportunities and limitations, and development prospects. Hence, it is rich in different basic structures and forms, i.e. functional and development specificities.

Having used the aforementioned criteria, the Republic of Srpska space was conditionally divided into four spatial units at different development levels, with most widely spatially distributed problem areas (Figure 1, Table 1). 


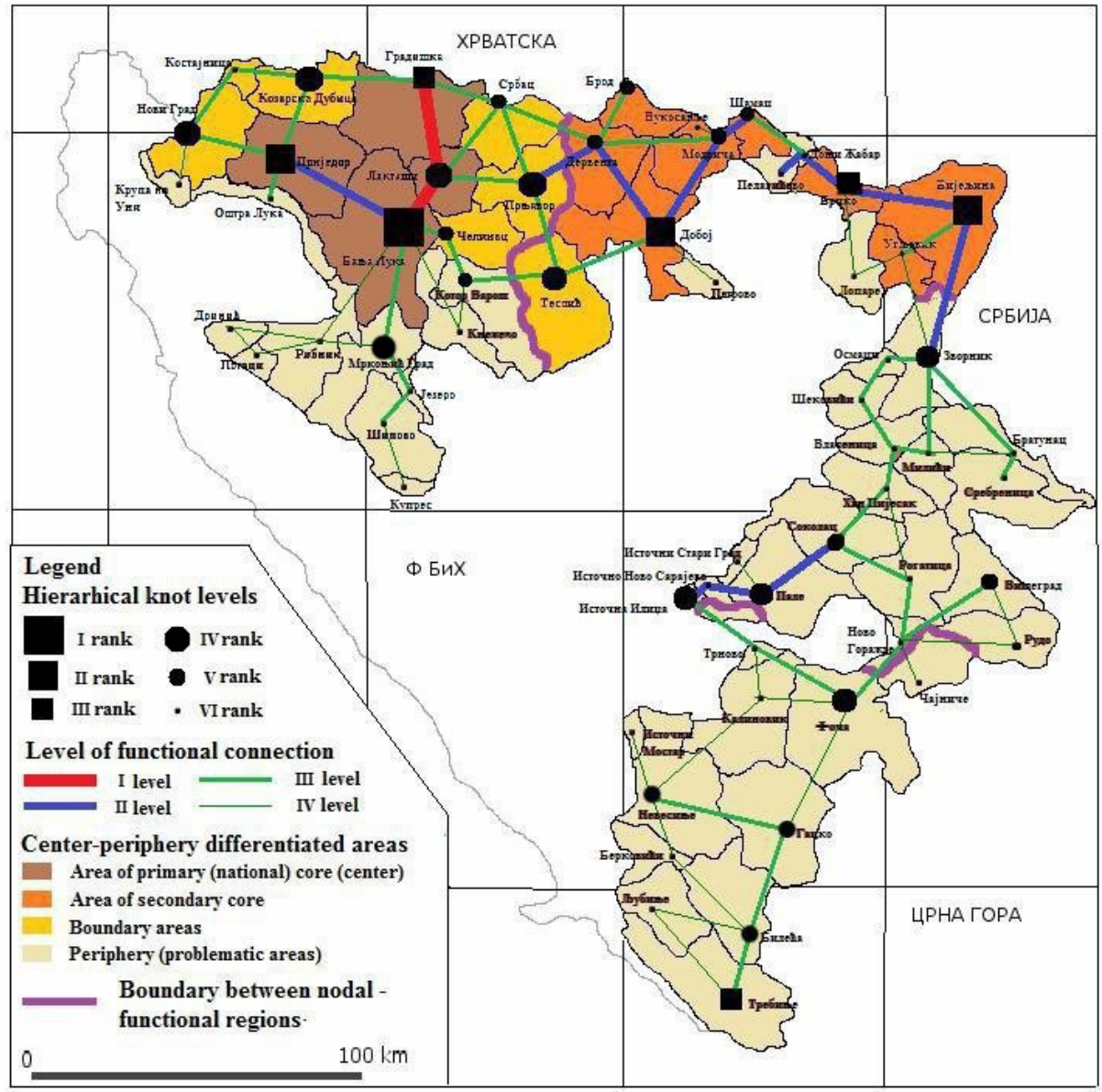

Figure 1.Spatial differentiation of the Republic of Srpska according to the center-periphery model

(Source: ЖиВковић, М., Папић, Д., Станојевић, М.. (2013); Business entities and the number of employees per sectors in the Republic of Srpska in 2014 (2015), Statistical yearbook - the Republic Bureau of Statistics, the Republic of Srpska, Banjaluka; Population and household census in Republic of Srpska in 2013. The Republic Institute of Statistics.

Banjaluka. 2017

The problem area of the Republic of Srpska completely covers the territory of Sarajevo-Zvornik and Trebinje-Foča regions (east of the Republic of Srpska), the southern part of Banjaluka region, and some minor administrative-territorial units (municipalities) in Doboj-Bijeljina region (Fig. 1). The problem area comprises $61 \%$ of Republic of Srpska territory $\left(15044 \mathrm{~km}^{2}\right)$. Both mean (26 people/ $\mathrm{km}^{2}$ ) and total (34\% of total Republic of Srpska population) population densities 
are poor (Tab.1). In addition, it is an emigrational region characterized with decades of continuous depopulation. The constant emigration of the young population of working age abates the social energy of problem area affecting both demographical and total sustainability.

Table 1.Spatial demographical disparity and demographical capacity of the Republic of Srpska according to the center-periphery model

\begin{tabular}{|c|c|c|c|c|c|c|c|c|c|}
\hline Area & 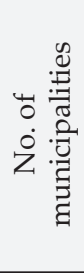 & 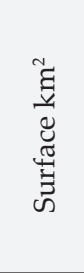 & $\begin{array}{l}0 \\
0 \\
0 \\
0 \\
0 \\
0 \\
0 \\
0 \\
0 \\
0 \\
0\end{array}$ & 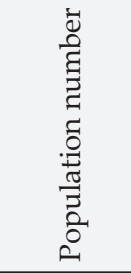 & 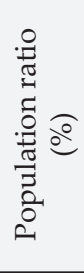 & 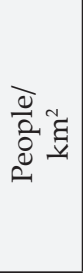 & 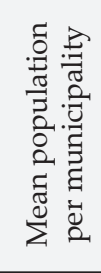 & 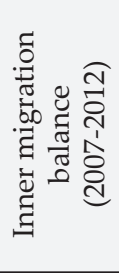 & 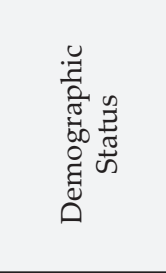 \\
\hline $\begin{array}{l}\text { Primary core } \\
\text { (center) }\end{array}$ & 4 & 3193 & 13 & 344375 & 30 & 108 & 86094 & 7882 & Stable \\
\hline $\begin{array}{c}\text { Secondary } \\
\text { core }\end{array}$ & 8 & 3010 & 12 & 274309 & 23 & 91 & 34289 & 2889 & $\begin{array}{c}\text { relatively } \\
\text { stable }\end{array}$ \\
\hline $\begin{array}{c}\text { Boundary } \\
\text { area }\end{array}$ & 7 & 3340 & 14 & 155209 & 13 & 46 & 22173 & -1242 & Endangered \\
\hline Periphery & 43 & 15044 & 61 & 396449 & 34 & 26 & 9220 & -3109 & $\begin{array}{c}\text { highly } \\
\text { endangered }\end{array}$ \\
\hline RS total & 62 & 24587 & 100 & 1170342 & 100 & 48 & 18876 & & Endangered \\
\hline
\end{tabular}

Source: 2012 Statistical Yearbook of Republic of Srpska. The Republic Institute of Statistics, 2012. Banjaluka. Population and household census in BiH in 2013.Republic of Srpska territory, 2013, Banjaluka

According to the current typology of demographical resource index, problem areas in the Republic of Srpska belong to the category of highly endangered districts (Mandić and Živković, 2014). The poor spatial-functional structure, the insufficient functionality of development centers, and the lack of nodal-functional relations and integrations are all typical of problem areas (Fig. 1, Tab. 2).

Regardless of the functionality level and hierarchy, the majority of central settlements lack the functional capacity necessary to perform their role within the spatial-functional organization. Most central settlements (i.e. municipal centers) are of a lowest functional ranking (Tab. 2) and largely "fail to meet the basic functional needs of the gravitation area and encourage the development processes"(Живковић, М., Папић, Д., Станојевић, М.. 2013, 318). The fact is that $72 \%$ of total municipal centers in problem areas belong to this category, i.e. the municipal centers within the category of highly endangered districts make $91 \%$ of all such centers in the Republic of Srpska (Tab.2). Having comparatively analyzed the functional and demographical capacities of settlements, we determined the collocation between these two, leading eventually to the sustainable 
development. The inadequate functional capacities of urban and degraded rural systems within the problem areas are the fundamental development issue that might threat both their and total sustainable development. Generally, problem areas are facing a whole range of development issues and prerequisites based upon both actual and possible valorization of the autochthon natural potentials.

In addition, "functional connections and functional dependency of crossboundary centers between the neighboring countries (corresponding settlements) and the cultural-civilization association define the cross-boundary nature of Bosnia and Herzegovina", i.e. Republic of Srpska, " which in addition determines a pertinent component of the comparative advantages of the country's development" (Živković, Mandić, Papić, Stanojević, 2016a,328).

Table 2.Classification of municipal centers according to the level of functional capacities

\begin{tabular}{|c|c|c|c|c|c|c|c|}
\hline \multirow{2}{*}{ Area } & \multicolumn{7}{|c|}{ Level of functional capacity } \\
\cline { 2 - 8 } & I & II & III & IV & V & VI & Total \\
\hline Primary core & 1 & 1 & 1 & 1 & - & - & 4 \\
\hline Secondary core & - & 2 & - & - & 4 & 2 & 8 \\
\hline Boundary area & - & - & - & 4 & 2 & 1 & 7 \\
\hline Periphery & - & - & 1 & 5 & 6 & 31 & 43 \\
\hline RS total & 1 & 3 & 2 & 10 & 12 & 34 & 62 \\
\hline
\end{tabular}

Source: Number of vehicles within the traffic network in the Republic of Srpska 2009. Road Directorate. Banjaluka. 2012; Business entities and the number of employees per sectors in the Republic of Srpska in 2014 (2015), Statistical yearbook - the Republic Bureau of Statistics, the Republic of Srpska, Banjaluka; 2013 Population and household census in the Republic of Srpska. The Republic Institute of Statistics. Banjaluka. 2017

Depending on the nature of development problems and processes and their territorial distribution, along with a whole range of other development issues, we may conditionally distinguish between the following problem areas in the Republic of Srpska:

- Regional problem areas

- National problem areas.

Spatially differentiated structural and dynamic development problems are a consequence of the cumulative impact of a whole range of development factors. The regional problem areas cover the southern part of Banjaluka region and some minor administrative-territorial units (municipalities) of Doboj-Bijeljina region. On the other hand, the national problem areas cover the eastern part of the Republic of Srpska, i.e. the functional-gravitational areas of SarajevoZvornik and Trebinje-Foca regions (Fig.1 and Tab. 3).

The southern part of Banjaluka region is the problem area of a regional level. Hereby, we refer to the functional-gravitational area of Mrkonjic Grad, 
which is a regional subsystem (mesoregion) of Banjaluka region. It is characterized by poor population density and inadequate nodal functions and internodal functional integrations (Fig. 1 and Tab. 3), which is a direct consequence of a whole range of negative historical-geographical development factors, development policies, war destruction and inadequate modern system transition.

From the natural-geographical aspect, the area belongs to the mountain-ravine landform. The development functions and their sustainability are directly connected with the current and possible valorization of the natural substratum. The optimum valorization of eco-vegetation, eco-climate, and forest complexes (55\% of total territory) is crucial for the stimulation of development of the key functions within the area. The development should be based upon forestry and tourism as well as the specialized agricultural and industrial production. Finally, it entails the revitalization of the defined geo-system and its total sustainability.

Problem areas of Doboj-Bijeljina region refer to the disconnected administrative-territorial units (municipalities) under the nodal-functional impact of cities of Doboj and Bijeljina. These are mostly rural areas in which the municipal centers are of lowest functional rankings (Figure 1). In addition, they represent areas of earlier municipal peripheries, which have been singled out as separate local units (municipalities) as a consequence of the earlier war (1992-1995) period. Affiliation to the Pannonian Basin determines the qualitative specificities. Plough-fields ( $45 \%$ of total territory) are the basis for the agrarian development and they open a whole range of opportunities for development functions, which also make the basic values of the system sustainability. Furthermore, the functional features of Doboj-Bijeljina region determine the development potentials and coherent development processes, which may further lead towards a more intensive inclusion of the problem areas into the regional associations. Finally, the result may be a more rapid revitalization.

Table 3. Problem areas of the Republic of Srpska and the spatial population distribution

\begin{tabular}{|l|c|c|c|c|c|c|}
\hline \multicolumn{1}{|c|}{ Problems area } & $\begin{array}{c}\text { Number of } \\
\text { municipalities }\end{array}$ & $\begin{array}{c}\text { Surface } \\
\text { in } \mathbf{k m}^{2}\end{array}$ & $\begin{array}{c}\text { Surface } \\
\text { ratio (\%) }\end{array}$ & $\begin{array}{c}\text { Population } \\
\text { number }\end{array}$ & $\begin{array}{c}\text { Population } \\
\text { ratio (\%) }\end{array}$ & $\begin{array}{c}\text { Population } \\
\text { density } \\
\text { people/ } \mathbf{k m}^{2}\end{array}$ \\
\hline $\begin{array}{l}\text { South Banjaluka } \\
\text { region }\end{array}$ & 11 & 3261 & 22 & 65492 & 17 & 20 \\
\hline $\begin{array}{l}\text { Parts of Doboj- } \\
\text { Bijeljina region }\end{array}$ & 4 & 606 & 4 & 29033 & 7 & 48 \\
\hline $\begin{array}{l}\text { Sarajevo-Zvornik } \\
\text { region }\end{array}$ & 17 & 5217 & 35 & 210018 & 53 & 40 \\
\hline Trebinje-Foca region & 11 & 5960 & 39 & 91906 & 23 & 15 \\
\hline Total & 43 & 15044 & 100 & 396449 & 100 & 26 \\
\hline
\end{tabular}

Source: Population and household census in Republic of Srpska in 2013.

The Republic Institute of Statistics. Banjaluka. 2017 
Eastern part of the Republic of Srpska is considered to be a peripheral problem area, i.e. a problem area of a national level. This is a borderline among the Republic of Srpska (i.e. Bosnia and Herzegovina), Serbia, Montenegro, and Croatia (Fig. 1). It covers more than $11000 \mathrm{~km}^{2}$ (45\% of total Republic of Srpska territory) and has the population of 301924 (26\% of total Republic of Srpska population).

These are extremely bipolar and bi-centric regions under the impact of East Sarajevo and Zvornik, and Trebinje and Foca (Fig. 1 and Tab. 3). From the natural geographical aspect, it mostly belongs to mountain-ravine landform, and some minor parts in north and south belong to Peri-Pannonian and Adriatic areas. The morphological, climate, and bio-geographical differentiation is highly articulated. The geo-diversity, manifested via different natural and anthropogenic systems, offers a whole range of both development opportunities and limitations. The crucial development problems are limited by the poor spatialfunctional structure (Figure 1). The insufficient development of service industry and lack of incentives within the urban centers of different level of centralism, in which the polarized role is dominant, are the basic development problems that result in negative economic, social, demographic, and other effects. To some extent, the aforementioned state of affairs results from the natural factors within the south of the region that belongs to the karst zone as well as from the total historical-geographical development and modern weaknesses of the system institutions, which consequentially affects the development functions and their role in the regional congregation.

We might be able to define the development strategy in compliance with the needs of sustainable development if we performed the following: a rational valorization of the available natural resources (ore, forests, hydro-energy, karst fields, etc.); foundation of development functions upon the provided natural substratum; polycentric development; trans-boundary regional development; and finally taking into account the optimum institutional capacity of the region. Hereby, we stress out that "cross-boundary cooperation and cross-boundary regional development with Serbia and Montenegro within boundary area with the Republic of Srpska (B\&H), as these are of similar natural-geographical and social-economic characteristics, are the basic prerequisite for sustainable development of the defined boundary areas of these countries" (Živković, Mandić, Papić, Stanojević, 2016 b, 211).

\section{Conclusion}

The growing differences within the Republic of Srpska spatial development, followed by a range of different development problems, are a threat to its 
sustainable development. Basically, the problem areas are characterized by the destruction of geo-spatial systems, which may lead towards the loss of demographical potential and development functions.

The nature of development problems in the Republic of Srpska assumes a development strategy that would rest upon the integral planning, i.e. the policy of territorial cohesion. Furthermore, there must be harmonization among the economic growth, social needs, and environment quality. Hence, it is necessary to observe the development issues in accordance with the model of integral territorial approach and new forms of problem area competition based upon the principles of sustainability.

In order to improve the competitiveness and total sustainability of our target problem areas and reach the economic, social, and territorial cohesion of the Republic of Srpska, it is necessary to perform an optimum valorization of the existing and attainable development prospects (territorial capital) and work on the polycentric development, functional networking of development centers, and regional trans-boundary development and cooperation.

\section{References}

Business entities and the number of employees per sectors in the Republic of Srpska in 2014 (2015), Statistical yearbook - the Republic Bureau of Statistics, the Republic of Srpska, Banjaluka

Ковјанић, А. (2016). Социоекономске детерминанте Ваније као проблемске регије, Зборник радова - Географски факултет Универзитета у Београду, 64, 177199

Mandić, M., \& Živković, M. (2014). Problematic areas of the Republic of Srpska within the context of demographic changes. Zbornik Matice Srpske za društvene nauke, Vol. 148 (3/2014)

Matišić, M., \& Pejnović, D. (2015). Uzroci i posljedice zaostajanja Istočne Hrvatske u regionalnom razvoju Hrvatske. Hrvatski geografski glasnik, 77(2), 101-140

Number of vehicles within the traffic network in the Republic of Srpska 2009. Road Directorate.Banjaluka.2012

Population and household census in Republic of Srpska in 2013.The Republic Institute of Statistics.Banjaluka. 2017

Statistical yearbook of the Republic of Srpska.The Republic Institute of Statistics. Banjaluka. 2012

Morais Mourato, J. \& Tewdrw-Jones. M. (2012). Europeanisation of domestic spatial planning, Exsposing apparent deiferences or unspoken convergence? In W. Zonneveld, J. De Vries \& L. Janssen-Jansen (eds) European Territorial Governance (pp. 157-173) (Housing and Urban Policy Studies, 35, IOS Press 
Тошић, Д. (2012). Принципи регионализације. Београд: Географски факултет Универзитета у Београду.

Živković, M., Mandić, M., Papić, D., \& Stanojević, M. (2016). Cross-boundary cooperation as a factor of development of Bosnia and Herzegovina within the EU integration processes, International Journal of Economics and Management Systems, Vol. 1, pp. 208-213

Živković, M., Mandić, M., Papić, D., \& Stanojević, M. (2016). Cross-boundary cooperation in service of development of Bosnia and Herzegovina - the sample of priority backward areas along the borderline, WSEAS TRANSACTION of ENVIRONMENT and DEVELOPMENT, Vol. 12, pp. 326-331

Живковић, М., Папић, Д., \& Станојевић, М.. (2013). Трансгранични развој у функцији рјешавања регионалних диспаритета Републике Српске, Зборник обиљежавања 20. годишъице ГДРС, Бања Лука

Winkler, A. (2012). Measuring regional ineqtuality: an index of socio-ekonomic pressure for Serbia. Зборник радова - Географски факултет Универзитета у Београду, 60, 81-102 